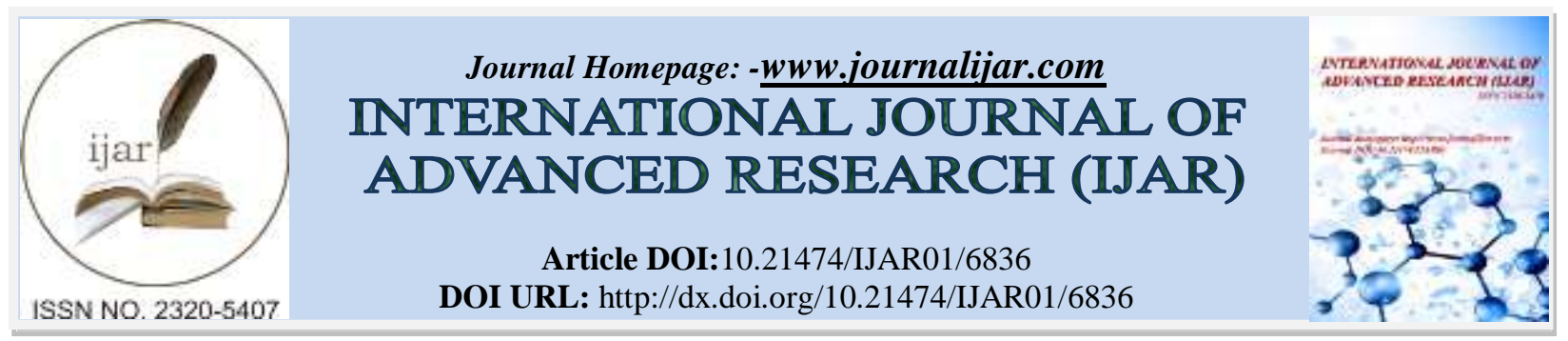

RESEARCH ARTICLE

\title{
TREACHER COLLIN'S SYNDROME: A CASE REPORT WITH AN AUGMENTED REVIEW!
}

\section{Christopher Vinay Shinde ${ }^{1}$ and Sahil Kohli ${ }^{2}$.}

1. Senior Lecturer, Department of Oral Medicine and Radiology, Mansarovar Dental College Hospital and Research Centre, Bhopal, MP, India

2. Senior Lecturer, Department of Oral Medicine and Radiology, RKDF Dental College and Research Centre, Bhopal, MP, India.

\section{Manuscript Info}

Manuscript History

Received: 03 February 2018

Final Accepted: 05 March 2018

Published: April 2018

\section{Abstract}

Copy Right, IJAR, 2018,. All rights reserved.

\section{Introduction:-}

Treacher Collin's syndrome (TCS) is named after Edward Treacher Collins (1862-1932), an English surgeon and ophthalmologist who described its essential traits in 1900. ${ }^{1}$ Infact first extensive description of the condition was produced by Franceschetti and Klein in 1949, who used the term Mandibulofacial dysostosis. ${ }^{2}$ Early descriptions were given by Berry (1889), Treacher Collins (1900), and Franceschetti and Klein (1949), and hence also known as Berry's syndrome and Franceschetti-Zwahlen-Klein syndrome. ${ }_{5}^{3,4}$ Incidence is estimated to range from 1 in 40,000 to 1 in 70,000 of live births. ${ }^{5}$

TCS is caused by mutation in TC0F1or 'Treacle', POLR1C, and POLR1D genes. The TCOF1 gene is located in distal portion of long arm of chromosome 5 (5q31.3-q33.3), genes POLR1C (6q21.2) and POLR1D (13q12.2) are located in chromosome 6 and chromosome 12 respectively. Other factors such as vitamin deficiency, malnutrient pregnant women, coalescence of amnion strings, attempted abortions, radiation, pressure, uterine hemorrhage, variation in temperature, diabetes, certain drugs, diptheria, toxoplasmosis, measles, rubella, influenza, maternal age, tumors, nervous shock, marital difficulties, socioeconomic conditions etc. are considered to have an etiological influence on TCS. ${ }^{6}$

TCS affects the development of structures derived from the first and second branchial arches during early embryonic development. ${ }^{7}$ It may appear under different clinical types but some of the consistent findings include antimongoloid palpebral fissures, coloboma of lower eyelids, micrognathia, malar hypoplasia, auditory canal abnormalities, conductive hearing loss, high arched palate and nasal deformity. ${ }^{8}$

Diagnosis is mainly based on clinical features and radiographic findings. Genetic counselling is highly recommended for affected individuals and their families for prevention of further affected child birth.

\section{Case Report:-}

A 17-year-old male patient reported with a chief complaint of malaligned teeth and desired to get the same corrected. The patient presented with atypical facial features, he had a relatively prominent nose and a characteristic 
fish/ bird like mouth with incompetent lips. He had a convex profile due to poor malar growth and severely retruded mandible. The clinical features can be divided into three groups: otological, ophthalmic and oral/dental.

On ENT examination there were large and everted ears, narrow nasal cavity, deviated nasal septum and soft palate drooping downward. There was no conductive hearing loss found in our case. Ophthalmic features included laterally downward sloping palpebral fissures (antimongoloid obliquity). Notching of outer part of lower eyelids (colobomas) was seen and deficiency of the lower eyelashes (medial to colobomas) was present [Figure-1a,b]. There was no visual defect associated.

Further examination revealed mouth opening was deviated to right side. Incompetent lips, micrognathia due to hypoplastic mandible and overall facial appearance could be described as bird/fish like.

Intraoral examination revealed a high arched palate and malocclusion (Angles Class II) with anterior open bite and V-shaped lower arch [Figure-2]. Dryness of mouth due to mouth breathing was present. Due to severe malocclusion erythematous gingiva with bleeding on probing and stains, calculus was present. This revealed poor oral hygiene with halitosis.

A provisional diagnosis of Treacher Collin's syndrome was given and radiographs were advised.

\section{Radiographic Features:-}

Orthopantomograph revealed a short mandibular ramii with a steep mandibular angle and an accentuation of the antegonial notch. The zygomatic arch was directed superiomedially. Crowding of teeth and Cupid bow shaped occlusal plane was present [Figure-3].

Lateral skull view revealed underdeveloped condylar and coronoid processes, deficient mandibular ramus, hypoplastic zygomatic bone, proclined upper anterior teeth and retrognathic mandible [Figure-4].

PA skull view revealed underdeveloped supraorbital ridges, defective lower margin of the orbit, hypoplasia of condyle and coronoid process, malocclusion, micrognathia, underdeveloped paranasal sinuses and mastoids [Figure5].

Correlating the clinical and radiological findings a diagnosis of Treacher Collin's syndrome was made. Oral prophylaxis was done and orthognathic surgery followed by comprehensive orthodontic therapy was advised. Also genetic counselling was provided to the patient.

\section{Differential Diagnosis:-}

Nager syndrome, Miller syndrome, Goldenhar syndrome, Hemifacial microsomia, Dominantly inherited and Xlinked maxillofacial dysostosis (Table-1).

Table-1:- List Of Differential Diagnosis In TCS:

\begin{tabular}{|l|l|}
\hline DIFFERENTIAL DIAGNOSIS & \multicolumn{1}{|c|}{ FEATURES: ${ }^{3,9}$} \\
\hline NAGER SYNDROME & $\begin{array}{l}\text { Features of TCS+ } \\
\text { mandible more hypoplastic, lower eyelid colobomas rare, and preaxial limb } \\
\text { abnormalities. }\end{array}$ \\
\hline MILLER SYNDROME & $\begin{array}{l}\text { Features of TCS+ } \\
\text { postaxial limb defects, ectropion or out turning of the lower eyelids. } \\
\text { Frequently cleft lip, with or without cleft palate, sometimes congenital heart } \\
\text { defects present. }\end{array}$ \\
\hline GOLDENHAR SYNDROME & $\begin{array}{l}\text { Features of TCS+ } \\
\text { vertebral abnormalities, epibulbardermoids and facial deformities. }\end{array}$ \\
\hline HEMIFACIAL MICROSOMIA & Reduced development of the ear, mouth, and mandible on one side only \\
\hline $\begin{array}{l}\text { DOMINANTLY INHERITED AND } \\
\text { X-LINKED MAXILLOFACIAL } \\
\text { DYSOSTOSIS }\end{array}$ & $\begin{array}{l}\text { Bilateral malar hypoplasia, maxillary hypoplasia, open bite, and downward- } \\
\text { slanting palpebral fissures without colobomas, relative mandibular } \\
\text { prognathism. }\end{array}$ \\
\hline
\end{tabular}


Figure-1a,b:- Frontal And Lateral View Of The Patient.

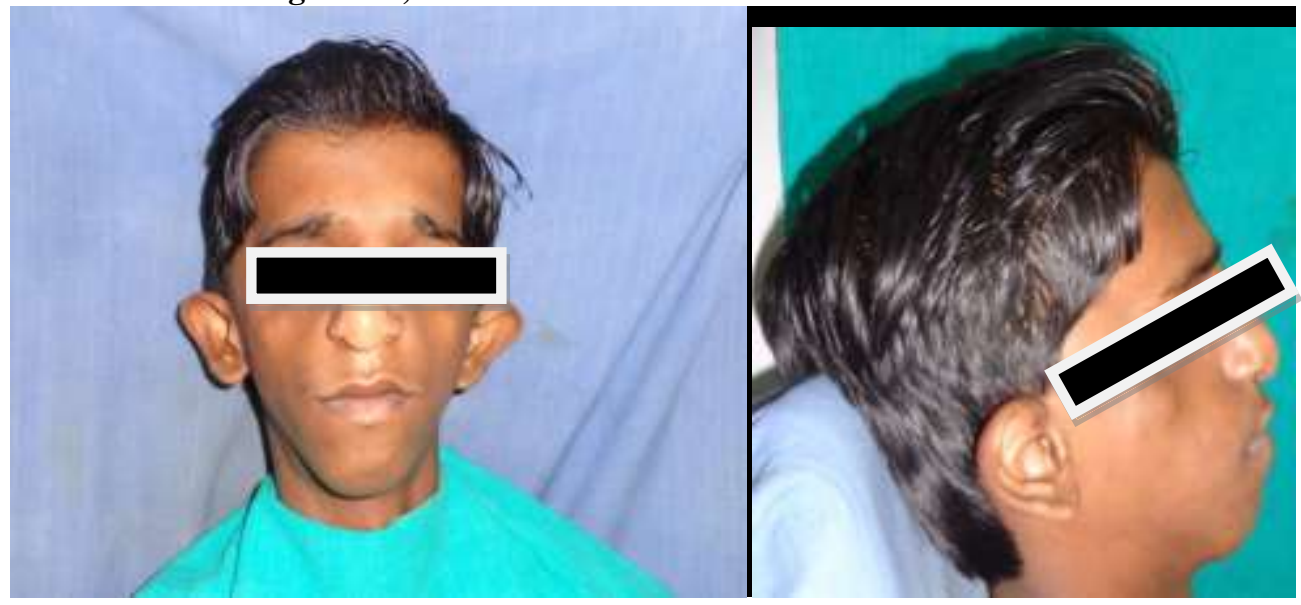

Figure-2:- Malocclusion.

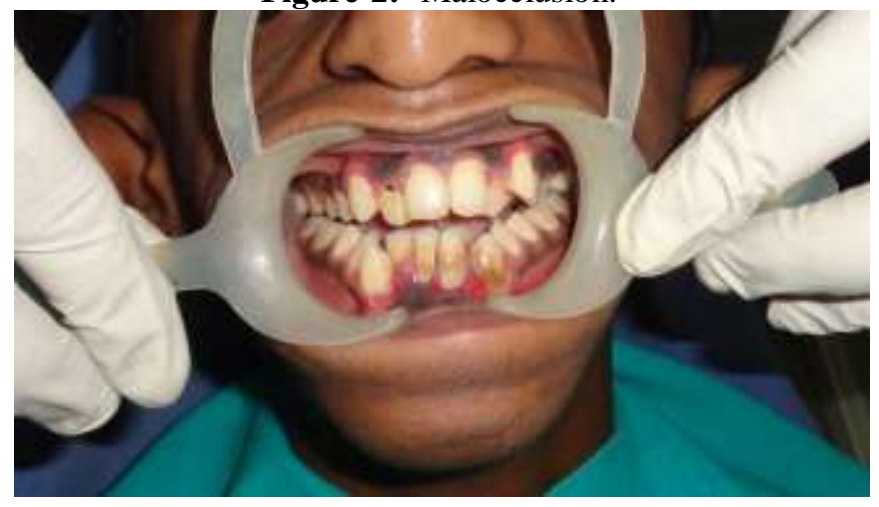

Figure-3:- Orthopantomograph Of The Patient.

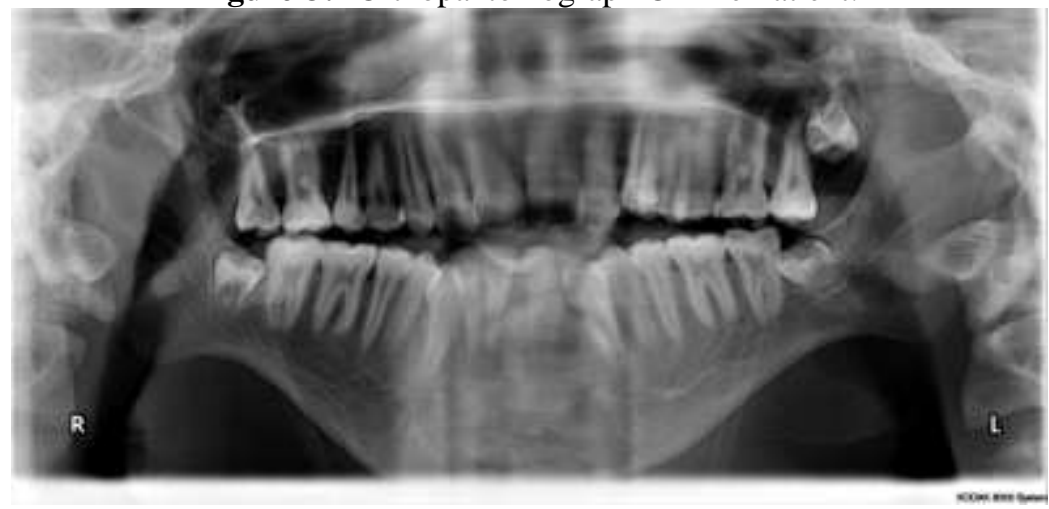


Figure-4:- Lateral Skull View.

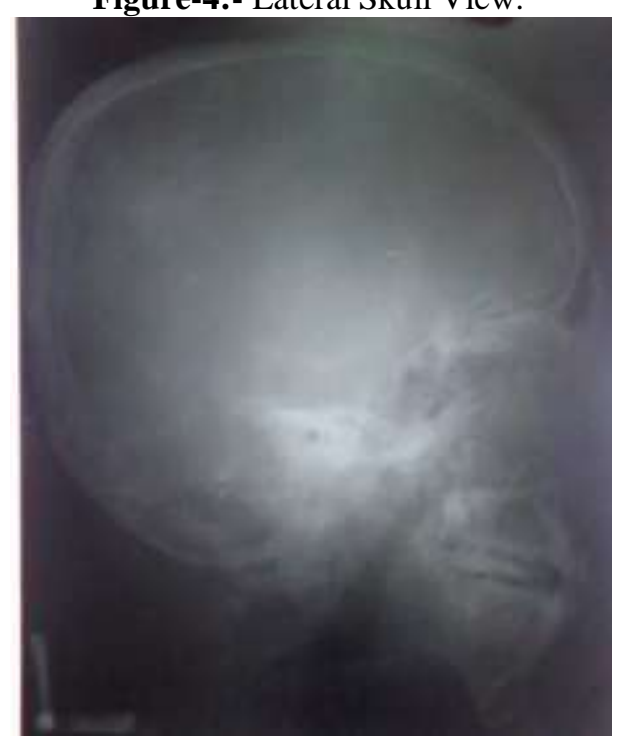

Figure-5:- Posteroanterior Skull View

\section{Discussion:-}

TCS is an autosomal dominant disorder where $40 \%$ of the affected patients have previous family history and the remaining $60 \%$ of cases arising as a result of a de novo mutation. It has been postulated that TCS represents a defect of blastogenesis that could be attributed to interference in cephalic neural crest cell histodifferentiation which occur at around $2^{\text {nd }}$ to $8^{\text {th }}$ week of embryonic life. ${ }^{9}$

In 1963, Axelsson et al named the following features as obligatory for the diagnosis of TCS: (1) antimongoloid palpebral fissures; (2) anomaly of the lower eyelid: coloboma of the outer third, or deficient lashes, or both; (3) hypoplasia of the malar bones; and (4) hypoplasia of the mandible. ${ }^{10}$ Our case had all these features.

Franceschetti and Klein described five clinical forms: (1) the complete form (having all known features), (2) the incomplete form (presenting variably with less severe ear, eye, zygoma, and mandibular abnormalities), (3) the abortive form (only the lower eyelid pseudocoloboma and zygoma hypoplasia are present), (4) the unilateral form, (anomalies limited to one side of the face), and (5) the atypical form (combined with other abnormalities not usually part of the typical syndrome). In our case, patient presented incomplete form of syndrome. As the patient had no affected family member, he may be considered a case of de novo mutation. Therefore, it is unlikely that the siblings would be affected. 
Prenatal testing of the TCS can be done by---Molecular genetic testing: DNA analysis of fetal cells by aminocentesis at 15-18 weeks of gestation or chorion villous sampling at 10-12 weeks of gestation to detect affected gene of chromosome. Ultrasound: in pregnant women may aid in risk findings like polyhydramnios, microcephaly and abnormal facial features. ${ }^{11}$ Preimplantion genetic diagnosis: in families where the causing mutation has been identified in an affected family member.

According to Marsazlek et $\mathrm{al}^{12}$ and Behrent et $\mathrm{al}^{13}$ characteristics of TCS can be categorised into obligatory, common and infrequent features as in Table-2.

Table-2:-Clinical Features In TCS:

\begin{tabular}{|l|l|l|}
\hline OBLIGATORY FEATURES & COMMON FEATURES & INFREQUENT FEATURES \\
\hline Antimongoloid palpebral fissures & Malocclusion & Hypertelorism \\
\hline Coloboma of lower eyelids & Open bite & Colobomas of upper eyelid \\
\hline Eyelash malformation & Deafness & Cleft palate \\
\hline Mandible defect & Macrostomia & Parotid gland agenesis \\
\hline Malar hypoplasia & Nasal deformity & Frontal sinus deficiency \\
\hline Preauricular hair displacement & High arched palate & Styloid process malformation \\
\hline Micrognathia & Auricular malformation & Mental retardation \\
\hline Fish like appearance & Skeletal deformity & Sella turcica defect \\
\hline
\end{tabular}

There is no cure for TCS, and treatment is tailored to the specific needs of each individual. Usually TCS patients have a poor oral hygiene because of mouth breathing and malocclusion. Therefore severe gingivitis, dental caries and early periodontal involvement is quite common.

At the same time these patients may be challenging due to the presence of other medical complications such as congenital heart defects, decreased oropharyngeal airways, hearing loss and anxiety toward treatment.

The current approach for clinical deformities seeks functional and esthetical corrections as well as psychosocial support since patients carry a social stigma because of severe facial deformities. Multidisciplinary approach including otorhinolaryngologists, craniofacial surgeons, ophthalmologists, speech therapists, psychologists and pediatric dentist, is the most appropriate way to manage these patients. ${ }^{14}$

Depending on the severity of the TCS, the patient may need some or all of the following procedures: tracheostomy at birth, conductive hearing aid, multiple surgeries to correct eyelid coloboma and cleft palate (in the early years) followed by orbital reconstruction and maxillomandibular osteotomies (at about 5-7 years of age), repair of cheek bones, repair of eyelid notches, correction of the undeveloped jaw and chin with mandibular surgery and sometimes plastic surgery to correct the beak-like nose and reconstruction of the ear. ${ }^{15,16}$

Older individuals depending on severity may require orthognathic combined with orthodontic approach for expansion of the jaws. This can be in of the form of upper-facial reconstruction, mandibular lengthening by distraction osteogenesis technique and orthognathic surgery to correct the birdlike facial appearance and anterior open bite after distraction, and lipofilling for the correction of residual depressive deformities. ${ }^{17}$

The development of speech and language skills depends on the child's ability to hear during the first 3 years of life. As the great majority of these patients are of normal intelligence, early recognition of deafness and its correction with hearing aids or surgery, when possible, is of great importance for development. An affected parent of either sex will transmit the defect to $50 \%$ of his or her offspring in accordance with Mendelian laws of genetics. This emphasizes the importance of genetic counselling to affected individuals. ${ }^{15}$ 


\section{References:-}

1. Huston Katsanis S, Cutting GR. Treacher Collins Syndrome. In: Pagon RA, Bird TC, Dolan CR, Stephens K, editors. Gene Reviews [Internet]. Seattle (WA): University of Washington, Seattle; 1993- 2010: [updated 2006 Oct 27; cited 2010 Aug 20]. Available from ttp://www.ncbi.nlm.nih.gov/bookshelf/br.fcgi?book=gene\&part=tcs

2. Horiuchi K, Ariga T, Fujioka H, Kawashima K, Yamamoto Y, Igawa H, et al. Mutational analysis of the TCOF1 gene in 11 Japanese patients with Treacher Collins Syndrome and mechanism of mutagenesis. Am J Med Genet A 2005; 134:363-7.

3. Gorlin RJ, Cohen MM Jr, Levin LS. Syndromes of the Head and Neck. 3rd ed. New York: Oxford University Press; 1990. p. 649-52.

4. Posnick JC, Ruiz RL. Treacher Collins syndrome: Current evaluation, treatment, and future directions. Cleft Palate Craniofac J 2000;37:434.

5. Marszałek B, Wójcicki P, Kobus K, Trzeciak WH. Clinical features, treatment and genetic background of Treacher Collins syndrome. J Appl Genet 2001; 43:223-33.

6. Gopal SK, Kshatri JKS, Ramesh K. Treacher collins syndrome: a clinical case report. Int J Curr Res 2016; 8:31814-7.

7. Chen H. Atlas of genetic diagnosis and counselling. Humana press, Totowa, New Jersey2006.p.967-71.

8. Sarella LK, Dakey PK, Kamala C. Treacher -Collins syndrome. Inter J Medical Sci Res Prac 2014; 1:105-7.

9. Horiuchi K, Ariga T, Fujioka H, Kawashima K, Yamamoto Y, Igawa H, et al. Mutational analysis of the TCOF1 gene in 11 Japanese patients with Treacher Collins Syndrome and mechanism of mutagenesis. Am J Med Genet A 2005; 134:363-7.

10. Axelsson A, Brolin I, Engstrom H, Liden G. Dysostosis mandibulo-facialis. J Laryngol Otol 1963;77:575-92.

11. Rotten D, Levaillant JM, Martinez H, Ducou le Pointe H, Vicaut E. The fetal mandible: a 2D and 3D sonographic approach to the diagnosis of retrognathia and micrognathia. Ultrasound Obstet Gynecol 2002;19:122-30.

12. Marszalek B, Wojcicki P, Kobus K, Trzeciak W. Clinical features, treatment and genetic background of Treacher Collins syndrome. J Appl Genet 2002; 43:223-33.

13. Behrents R, McNamara J, Avery J. Prenatal mandibulofacial dysostosis (Treacher Collins 1. syndrome). Cleft Palate J 1977; 14:13.

14. Andrade EC, Júnior VS, Didoni AL, Freitas PZ, Carneiro AF, Yoshimoto FR. Treacher Collins syndrome with choanal atresia: A case report and review of disease features. Braz J Otorhinolaryngol 2005;71:107-10.

15. Kasat V, Baldawa R. Treacher Collins syndrome- a case report and review of literature. J Clin Exp Dent 2011;3(Suppl1):e395-9.

16. Shetty BS, Thomas A, Pidamale R. Treacher Collins Syndrome: a case report and a brief review on diagnostic aids. Int J Clin Pediatr Dent 2011; 4:235-9.

17. Vesna A. Treacher Collins Syndrome. Int Biol Biomed J Autumn 2017; 3:157-61. 